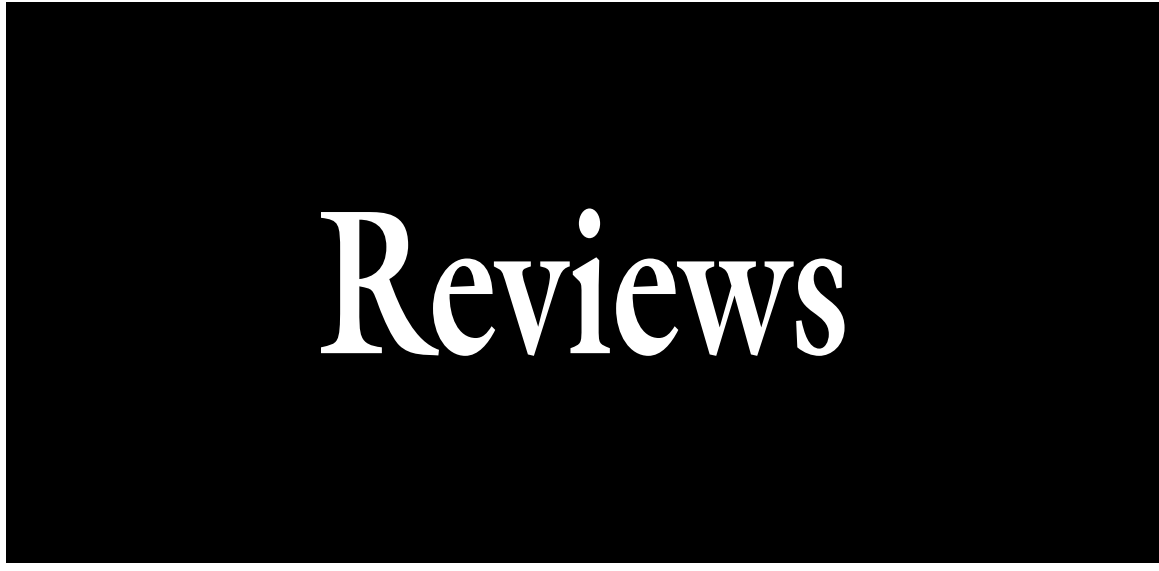

\section{Understanding Carbon Footprint in Production and Use of Landscape Plants}

\author{
Dewayne L. Ingram ${ }^{1,5}$, Charles R. Hall ${ }^{2,3}$, and Joshua Knight ${ }^{1,4}$
}

ADDITIONAL INDEX wORDs. global warming potential, life cycle assessment, sustainability, variable costs

SUMmARY. Understanding carbon footprint (CF) terminology and the science underlying its determination is important to minimizing the negative impacts of new product development and assessing positive or negative cradle-to-grave lifecycle impacts. Life cycle assessment has been used to characterize representative field-grown and container-grown landscape plants. The dominant contributor to the CF and variable costs of field-grown trees is equipment use, or more specifically, the combustion of fossil fuels. Most of that impact is at harvest when heavy equipment is used to dig and move individual trees. Transport of these trees to customers and the subsequent transplant in the landscape are also carbon-intensive activities. Field-grown shrubs are typically dug by hand and have much smaller CFs than trees. Plastics are the major contributor to CF of container-grown plants. Greenhouse heating also can be impactful on the CF of plants depending on the location of the greenhouse or nursery and the length and season(s) of production. Knowing the input products and activities that contribute most toward CF and costs during plant production allows nursery and greenhouse managers to consider protocol modifications that are most impactful on profit potential and environmental impact. Marketers of landscape plants need information about the economic and environmental life-cycle benefits of these products, as they market to environmentally conscious consumers.

$\mathrm{T}$ he purpose of this article was to provide a base of understanding of $\mathrm{CF}$ terminology and to illustrate $\mathrm{CF}$ analyses using data from previous research that modeled nursery and greenhouse crop production systems and their life-cycle impact. CF relates to the efflux of greenhouse gases in the environment. The greenhouse gas emissions ( $\mathrm{GHG}$ ) of primary interest are carbon dioxide $\left(\mathrm{CO}_{2}\right)$, nitrous oxide $\left(\mathrm{N}_{2} \mathrm{O}\right)$, and methane $\left(\mathrm{CH}_{4}\right)$ and result from human and environmental activities. They warm the earth by absorbing energy and decreasing the rate at which energy escapes the earth's atmosphere to space [U.S. Environmental Protection Agency (USEPA),
2018]. In other words, greenhouse gases increase the effectiveness of the atmosphere to act as a blanket that insulates the earth. Therefore, GHG have a measurable potential for trapping energy in the earth's atmosphere.

Greenhouse gases differ in their effectiveness to absorb energy in specific wavelengths, primarily infrared. This is referred to as their radiative efficiency (USEPA, 2018). They also differ in terms of how long they stay in the atmosphere, or their lifetime. Global warming potential (GWP) was developed to categorize greenhouse gases based on their radiative efficiency and lifetime in the atmosphere. The greenhouse gas of greatest concentration is $\mathrm{CO}_{2}$. The concentration of $\mathrm{CO}_{2}$ in the atmosphere has also been increasing, especially since the industrial revolution, and $\mathrm{CO}_{2}$ remains in the atmosphere for thousands of years. The combustion of fossil fuels has played a major role in this increase. Therefore, the GWP of emitted gases is expressed relative to the GWP of $\mathrm{CO}_{2}$ for a 100 -year period $\left(\mathrm{GWP}_{100}\right)$. The $\mathrm{GWP}_{100}$ of $\mathrm{CO}_{2}$ is set as 1 , the reference to which other GHGs are compared and expressed.

The CF, or GWP, of a product or activity is expressed in kilograms of $\mathrm{CO}_{2}$-equivalent $\left(\mathrm{CO}_{2} \mathrm{e}\right) \cdot \mathrm{CH}_{4}$ and $\mathrm{N}_{2} \mathrm{O}$ are estimated to have a GWP $_{100}$ of 28 to 36 and 165 to 298 times that of $\mathrm{CO}_{2}$, respectively. $\mathrm{CH}_{4}$ is released from animals, humans, natural wetlands, paddy rice (Oryza sativa) fields, fermentation, and biomass burning. Agriculture is a primary source of $\mathrm{N}_{2} \mathrm{O}$ emissions, as are industrial activities, municipal waste landfills, and combustion of fossil fuels. Although found in the atmosphere at extremely low concentrations, chlorofluorocarbons, hydrofluorocarbons, hydrochlorofluorocarbons, perfluorocarbons, and sulfur hexafluoride can have GWPs thousands or tens of thousands of times greater than $\mathrm{CO}_{2}$ (USEPA, 2018). These definitions were the basis for an international treaty, called the Kyoto Protocol, signed in 1997 that commits parties to reduce GHG, effective in 2005. The details of those definitions and targets for reduction have been published by the United Nations (2008). Additional related data have been published on The Intergovernmental Panel on Climate Change website of the United Nations (2018).

Tools to estimate GHG during the life cycle of a targeted product or activity have been developed over the years and

\begin{tabular}{llll}
\hline $\begin{array}{l}\text { Units } \\
\text { To convert U.S. to SI, } \\
\text { multiply by }\end{array}$ & U.S. unit & SI unit & $\begin{array}{l}\text { To convert SI to U.S., } \\
\text { multiply by }\end{array}$ \\
\hline 29.5735 & $\mathrm{fl} \mathrm{oz}$ & $\mathrm{mL}$ & 0.0338 \\
3.7854 & gal & $\mathrm{L}$ & 0.2642 \\
2.54 & inch(es) & $\mathrm{cm}$ & 0.3937 \\
0.4536 & $\mathrm{lb}$ & $\mathrm{kg}$ & 2.2046
\end{tabular}


have led to the development of a complex, yet systematic process called life cycle assessment [LCA (Ingram and Fernandez, 2012)]. This tool has international acceptance by the scientific community, is governed by international standards, and has application to many fields, including agriculture. Although there are periodic revisions of the standards, the authors of this article have followed the International Organization for Standardization revised standard (International Organization for Standardization, 2006) and British Standards Institution's standard (British Standards Institution, 2011). Under these standards, a functional unit of the targeted LCA is defined and all inputs are determined for the system. A functional unit may be anything from a gallon of milk or a container-grown shrub or a field-grown tree. GWP is but one environmental impact that can be measured or estimated by LCA. These potential environmental impact measures include water footprint, ecotoxicity, ozone depletion, acidification, eutrophication, and others (Ingram and Hall, 2014b). A complete cradle-to-grave LCA of a product or activity includes production, use, and post-life phases. However, a partial life-cycle impact, such as cradle-to-farm gate or seed-to-landscape, also can be defined, analyzed, and reported.

\section{Cradle-to-gate CF of nursery and landscape plants}

The CF of the components of production systems for the major crop categories for landscape plants

Received for publication 5 Nov. 2018. Accepted for publication 18 Dec. 2018.

Published online 31 January 2019.

This material is based on work that is supported by the National Institute of Food and Agriculture, U.S. Department of Agriculture, Specialty Crop Research Initiative, under award number 2014-51181-22372, and by a grant from The Horticulture Research Institute, 1200 G Street NW, Suite 800, Washington, DC 20005.

${ }^{1}$ Department of Horticulture, University of Kentucky, N-318 Agriculture Science North, Lexington, KY 40546-0091

${ }^{2}$ Department of Horticultural Sciences, Texas A\&M University, 2133 TAMU, College Station, TX 778432133

${ }^{3}$ Professor and Ellison Chair in International Floriculture

${ }^{4}$ Extension Associate

${ }^{5}$ Corresponding author. E-mail: dingram@uky.edu.

This is an open access article distributed under the CC BY-NC-ND license (https://creativecommons.org/ licenses/by-nc-nd/4.0/).

https://doi.org/10.21273/HORTTECH04220-18 has been modeled (Table 1 ), including a field-grown shade tree [red maple (Acer rubrum)], field-grown evergreen tree [blue spruce (Picea pungens)], field-grown flowering tree ['Forest Pansy' redbud (Cercis canadensis)], field-grown deciduous shrub [juddi viburnum (Viburnum $\times$ juddi)], fieldgrown evergreen shrub ['Densiformus' taxus (Taxus $\times$ media)], pot-in-pot shade tree [red maple (Acer rubrum)], container-grown evergreen shrub on the U.S. mid-Atlantic coast ['Bennett's Compacta' japanese holly (Ilex crenata)], container-grown evergreen shrub in the U.S. Pacific northwest region ['Green Beauty' boxwood (Buxus microphylla japonica)], herbaceous annual flowering plant [wax begonia (Begonia xsemperflorenscultorum)], young plants (foliage plants in 72-count trays), outdoor-grown flowering potted plant [chrysanthemum (Chrysanthemum)], and greenhousegrown flowering potted plant [poinsettia (Euphorbia pulcherrima)]. The primary purpose of this LCA modeling research was to identify inputs and processes in these production systems that contribute the most to $\mathrm{CF}$ and variable costs. Once these processes are identified and defined, managers know where to invest their time in seeking alternatives that would make the greatest difference in environmental impact and profitability.

Field production of trees and shrubs is still an important but decreasing portion of landscape plant production systems (Hodges et al., 2015). Analysis of production components of model systems for field-grown trees revealed that the farm-gate $\mathrm{CF}$ for 2 -inch caliper red maple and blue spruce was 12.5 and $7.9 \mathrm{~kg} \mathrm{CO} \mathrm{CO}_{2} \mathrm{e}$, respectively (Table $\mathrm{l}$ ). The farm-gate CF for a 2 -inch caliper flowering tree (redbud) model system was calculated to be $6.6 \mathrm{~kg} \mathrm{CO}_{2} \mathrm{e}$. Interestingly, $71 \%$ to $77 \%$ of the GHG for these field-grown tree model systems were due to equipment use and up to $89 \%$ of equipment use per plant occurred at harvest. This is logical given the fact that heavy equipment time was focused on individual trees for these operations. Input materials and equipment use in the harvesting process contributed an average of $26 \%$ of the total variable costs for field-grown tree models studied (Ingram and Hall, 2015b).
The model systems for fieldgrown shrubs are characterized by hand-digging and a much higher density of plant per area than for fieldgrown trees. The farm-gate $\mathrm{CF}$ for a model system for 36-inch juddi viburnum was $0.70 \mathrm{~kg} \mathrm{CO}_{2} \mathrm{e}$, whereas the model system for an evergreen shrub, 24-inch taxus, using a greenhouse propagation phase was calculated as $0.77 \mathrm{~kg} \mathrm{CO}_{2} \mathrm{e}$. More than $60 \%$ of CF for these field-grown shrubs was from input materials, whereas labor accounted for $71 \%$ to $77 \%$ of variable costs.

Container production has become the system by which most landscape plants are grown and marketed. Most container-grown trees and shrubs are hardy in a region and are grown on outdoor beds with full sun or artificial shade. Winter protection of these plants is required in many parts of the country to eliminate freeze damage to roots. The farmgate CF of \#3 $(11.4 \mathrm{~L})$ container shrubs ranged from 1.72 to $3.36 \mathrm{~kg}$ $\mathrm{CO}_{2} \mathrm{e}$ depending on the location and protocols for the model systems (Table 1). Variable costs for these model systems ranged from $\$ 2.88$ to $\$ 5.73$, influenced primarily by input materials and secondarily by labor, both of which varied by container size sequencing protocols.

Kendall and McPherson (2012) published the cutting-to-retail garden center $\mathrm{CF}$ in California for trees in \#5 (14.5 L) and \#9 (34 L) containers as 4.6 and $15.3 \mathrm{~kg} \mathrm{CO}_{2} \mathrm{e}$, respectively. Direct fuel use contributed nearly $50 \%$ of the CF but there was no way to determine how much of this was before the farm gate from the data presented. Input materials, including the container, constituted the second largest contributor to CF.

The farm-gate $\mathrm{CF}$ for a 2 -inch caliper red maple produced in a \#25 $(100 \mathrm{~L})$ container in a pot-in-pot production system in the lower-midwest United States was calculated to be $10.74 \mathrm{~kg} \mathrm{CO}_{2} \mathrm{e}$, of which $85 \%$ was due to input materials (Table 1 ). The insert or growing container contributed $30 \%$ of the input materials contributions to $\mathrm{CF}$. Input materials contributed $76 \%$ of variable costs, influenced significantly by the cost of the liner.

Although equipment use was the primary contributor to the farm-gate CF of field-grown plants, the use of plastics was the primary contributor 
Table 1. Farm-gate carbon footprint [global warming potential (GWP), carbon dioxide equivalents $\left(\mathrm{CO}_{2} \mathrm{e}\right)$ ] and variable costs for landscape plant production models using life cycle assessment.

\begin{tabular}{lccl}
\hline Plants modeled & GWP $\left(\mathbf{k g ~ C O} \mathbf{C O}_{2} \mathrm{e}\right)^{\mathrm{y}}$ & Variable costs $(\$)^{\text {Reference(s) }}$ & \multicolumn{1}{c}{ R } \\
\hline Red maple, B\&B & 12.5 & 36.66 & Ingram, 2012; Ingram and Hall, 2015c \\
'Forest Pansy' redbud, B\&B & 6.6 & 37.74 & Hall and Ingram, 2014; Ingram and Hall, 2013 \\
Blue spruce, B\&B & 7.9 & - & Ingram, 2013; Ingram and Hall, 2015c \\
Juddi viburnum, B\&B & 0.7 & 5.36 & Ingram and Hall, 2014a \\
'Densiformus' taxus, B\&B & 0.77 & 5.09 & Hall and Ingram, 2015 \\
Red maple, \#25 PNP & 10.74 & 55.49 & Ingram and Hall, 2015a \\
'Bennett's Compacta' japanese holly \#3, & 2.14 & 3.22 & Ingram et al., 2016 \\
$\quad$ U.S. mid-Atlantic region & & & \\
'Green Beauty' boxwood \#3, & $1.72-3.36$ & $2.88-5.73$ & Ingram et al., 2017a \\
$\quad$ U.S. Pacific northwest region & & & \\
Wax begonia, 4.5-inch & 0.14 & 0.67 & Ingram et al., 2018a \\
Young plants tray (72) & $2.28-4.22$ & $24.86-25.25$ & Ingram et al., 2017b \\
Chrysanthemum, 8-inch & 0.55 & 0.85 & Ingram et al., 2018b \\
Poinsettia, 6-inch & 0.47 & 1.03 & Ingram et al., 2019
\end{tabular}

${ }^{\mathrm{z}} \mathrm{B} \& \mathrm{~B}=$ balled and burlapped from field production system; \#25 PNP $=100$ - L container in a pot-in-pot production system; \#3 = 11.4 - $\mathrm{L}$ container size; 4.5 -inch $(675 \mathrm{~mL}), 8$ inch $(2.9 \mathrm{~L})$, and 6-inch $(1.7 \mathrm{~L})$ refer to container diameter; $(72)$ refers to the number of plants in the tray; $1 \mathrm{~L}=0.2642 \mathrm{gal}, 1 \mathrm{~mL}=0.0338 \mathrm{fl} \mathrm{oz}, \mathrm{l}$ inch $=2.54 \mathrm{~cm}$. ${ }^{\mathrm{y}} 1 \mathrm{~kg}=2.2046 \mathrm{lb}$

for container-grown woody plants. A research team in Italy also reported that use of plastics was a significant contributor to container-grown nursery crop CF (Beccaro et al., 2014).

Herbaceous annuals and many flowering potted plants are grown and marketed in containers. They are most often grown in greenhouses to facilitate production of these crops to satisfy spring or continuously available markets. Wax begonia produced in a greenhouse and marketed in a 4.5inch container as part of a 12-plant shuttle tray was modeled using LCA (Table 1). The CF was calculated for this 8-week crop model as $0.14 \mathrm{~kg}$ $\mathrm{CO}_{2} \mathrm{e}$ with variable costs of $\$ 0.67$. Fifty-seven percent of CF and $43 \%$ of variable costs in the model were from the container and shuttle tray. Heating contributed little to CF or variable costs due to rapid turnover and a limited number of months requiring heat. The CF of a greenhouse-grown poinsettia in a 6-inch container produced in the north Atlantic U.S. coast region was modeled at $0.47 \mathrm{~kg} \mathrm{CO}_{2} \mathrm{e}$, and variable costs were $\$ 1.03$. The substrate, container, and fertilization contributed 30\% of the CF. The unrooted cutting was $44 \%$ of the variable costs.

Young foliage plants in a 72count propagation tray in a variety of greenhouse systems was estimated to have a CF of 2.28 to $4.22 \mathrm{~kg} \mathrm{CO}_{2} \mathrm{e}$ and variable costs of $\$ 24.86$ to $\$ 25.25$ (Table 1). Electricity and heating costs, even in the deep south United States, were the major contributors to $\mathrm{CF}$ $(87 \%$ to $90 \%)$, and microcutting and

Table 2. The complete life-cycle carbon footprint [global warming potential (GWP), carbon dioxide equivalents $\left(\mathrm{CO}_{2} \mathrm{e}\right)$ ] for woody landscape plant production and use models from propagation through disposal weighted as a portion of a 100-year assessment period using life cycle assessment.

\begin{tabular}{lcl}
\hline Plants modeled & GWP $\left(\mathbf{k g ~ C O}_{2} \mathbf{e}\right)^{\mathbf{z}}$ & \multicolumn{1}{c}{ Reference } \\
\hline Red maple & -666 & Ingram and Hall, 2016 \\
Blue spruce & -430 & Ingram, 2013 \\
'Forest Pansy' redbud & -63 & Ingram and Hall, 2013 \\
Juddi viburnum & -11 & Ingram and Hall, 2014a \\
'Densiformus' taxus & -9 & Hall and Ingram, 2015 \\
\hline
\end{tabular}

${ }^{\mathrm{z}} 1 \mathrm{~kg}=2.2046 \mathrm{lb}$.

transplanting accounted for $77 \%$ of variable costs. Outdoor production of chrysanthemum in 8-inch containers was modeled to have a CF of $0.55 \mathrm{~kg}$ $\mathrm{CO}_{2} \mathrm{e}$ with variable costs of $\$ 0.85$. Although the container was an important contributor to CF, substrate components accounted for $45 \%$ of $\mathrm{CF}$ and $12 \%$ of variable costs.

\section{Impact of nursery and greenhouse plants in the landscape}

The impact of landscape plants on atmospheric $\mathrm{CO}_{2}$ during the production and use phases contributes to the life-cycle benefits. Although GHG occur during the production phase, $\mathrm{CO}_{2}$ is sequestered from the air and stored in the wood of plants. As $\mathrm{CO}_{2}$ is sequestered in wood, it is not contributing to the atmospheric concentration and not affecting GWP. Although plants differ in terms of the density of their wood, $\approx 50 \%$ of the dry weight of wood is carbon. Carbon is sequestered in growing woody plants at a rate based on increasing dry weight accumulation. A red maple in the lower-midwest United States is estimated to sequester $3632 \mathrm{~kg} \mathrm{CO}$ in a 60-year life (Ingram, 2012). However, the 60-year life expectancy of a red maple is less than the 100-year assessment period, and carbon sequestered in year 1 is held for 60 years but carbon sequestered in year 50 is held for only 10 years. Therefore, the impact on GWP by carbon sequestration in each year is weighted based on the portion of the 100-year assessment period.

Greenhouse gases also will be emitted when the tree is removed from the landscape at the end of its life. These GHGs are primarily the result of gasoline and diesel combustion in chain saws, chippers, and trucks. GHGs from take down and disposal were calculated to be 214 , 148 , and $88 \mathrm{~kg} \mathrm{CO}_{2} \mathrm{e}$ for red maple, blue spruce, and redbud, respectively (Ingram, 2012, 2013; Ingram and Hall, 2013). Take down and disposal of the shrubs in this study would result in $1.25 \mathrm{~kg} \mathrm{CO}_{2} \mathrm{e}$ GHG. 
The weighted positive impact on $\mathrm{CF}$ during the use phase is reduced to account for GHG during take down and disposal. The weighted life-cycle $\mathrm{CF}$ of modeled trees and shrubs is presented in Table 2. In the case of the red maple, the weighted life cycle $\mathrm{CF}$ is $-666 \mathrm{~kg} \mathrm{CO} 2 \mathrm{e}$; in other words, this reduction in atmospheric $\mathrm{CO}_{2}$ is a positive impact on tree life-cycle $\mathrm{CF}$ and protects the environment.

As the green industry continues to mature, differentiation is an increasingly important business strategy for green industry businesses. One such way to accomplish this is by adopting environmentally friendly behaviors and/or selling products that offer environmental benefits. Consumers' awareness and concern about environmental issues are exhibited by their interest in purchasing products that are designed to reduce long-term adverse environmental impacts. With regard to the green industry, the relationship between environmentally friendly business practices and consumer preferences suggests that nursery and greenhouse firms may realize financial benefits for their efforts toward designing environmentally sound products. In the current examples, planting shrubs and trees that more than offset the amount of GHGs that are generated during their production by the amount of $\mathrm{CO}_{2}$ they sequester during their life span could be emphasized during firm-level marketing efforts. From a demand standpoint, recent literature has substantiated that consumers increasingly consider the potential environmental impact of green industry products (e.g., CF) when making purchasing decisions (Hall, 2010; Yue et al., 2010, 2011).

This article has summarized the life-cycle impact of landscape plants on GWP. Herbaceous plant materials have minimal impact on GWP in the landscape; however, they contribute to environmental quality in other ways. Woody and herbaceous landscape plants provide many ecosystem services, including air quality improvement, microclimate enhancement, energy conservation, noise attenuation, and storm water management. They also contribute positively to human health and quality of life and increase property value (Hall and Dickson, 2011). Additional information about ecosystem services provided by landscape plants has been summarized in an Extension publication (Knight and
Ingram, 2017, 2018), documented in other publications (Hall, 2010; Hall and Dickson, 2011), and compiled online at ellisonchair.tamu.edu.

\section{Literature cited}

Beccaro, G.L., A.K. Cerutti, I. Vandecasteele, L. Bonvegna, D. Donno, and G. Bounous. 2014. Assessing environmental impacts of nursery production: Methodological issues and results from a case study in Italy. J. Clean. Prod. 80:159-169.

British Standards Institution. 2011. Specification for the assessment of the life cycle greenhouse gas emissions of goods and services. PAS 2050:2011 British Standards Institution, London, UK.

Hall, C.R. 2010. Making cents of green industry economics. HortTechnology 20:832-835.

Hall, C.R. and M.W. Dickson. 2011. Economic, environmental, and health/ well-being benefits associated with green industry products and services: A review. J. Environ. Hort. 29:96-103.

Hall, C.R. and D.L. Ingram. 2014. Production costs of field-grown Cercis canadensis L. 'Forest Pansy' identified during life cycle assessment analysis. HortScience 49:1-6.

Hall, C.R. and D.L. Ingram. 2015. Carbon footprint and production costs associated with varying the intensity of production practices during field-grown shrub production. HortScience 50:402407.

Hodges, A.W., C.R. Hall, M.A. Palma, and $\mathrm{H}$. Khachatryan. 2015. Economic contributions of the green industry in the United States in 2013. HortTechnology 141:805-814.

Ingram, D.L. 2012. Life cycle assessment of a field-grown red maple tree to estimate its carbon footprint components. Intl. J. Life Cycle Assess. 17:453-462.

Ingram, D.L. 2013. Life cycle assessment to study the carbon footprint of system components for colorado blue spruce field production and landscape use. J. Amer. Soc. Hort. Sci. 138:3-11.

Ingram, D.L. and R.T. Fernandez. 2012. Life cycle assessment: A tool for determining the environmental impact of horticultural crop production. HortTechnology 22:275-278.

Ingram, D.L. and C.R. Hall. 2013. Carbon footprint and related production costs of system components of a fieldgrown Cercis canadensis L. 'Forest Pansy' using life cycle assessment. J. Environ. Hort. 31:169-176.
Ingram, D.L. and C.R. Hall. 2014a. Carbon footprint and related production costs of system components for a fieldgrown Viburnum $x$ juddi using life cycle assessment. J. Environ. Hort. 32:175181.

Ingram, D.L. and C.R. Hall. 2014b. Life cycle assessment used to determine the potential environment impact factors and water footprint of field-grown tree production inputs and processes. J. Amer. Soc. Hort. Sci. 140:102-107.

Ingram, D.L. and C.R. Hall. 2015a. Carbon footprint and related production costs of pot-in-pot system components for red maple using life cycle assessment. J. Environ. Hort. 33:103-109.

Ingram, D.L. and C.R. Hall. 2015b. Using life cycle assessment (LCA) to determine the carbon footprint of trees during production, distribution and useful life as the basis for market differentiation. Acta Hort. 1090:35-38.

Ingram, D.L. and C.R. Hall. 2015c. Life cycle assessment used to determine the potential midpoint environment impact factors and water footprint of field-grown tree production inputs and processes. J. Amer. Soc. Hort. Sci. 140:102-107.

Ingram, D.L. and C.R. Hall. 2016. Comparison of carbon footprint and variable costs of selected nursery production systems for a $5-\mathrm{cm}$-caliper red maple. HortScience 51:383-387.

Ingram, D.L., C.R. Hall, and J. Knight. 2016. Carbon footprint and variable costs of production components for a containergrown evergreen shrub using life cycle assessment: An east coast U.S. model. HortScience 51:989-994.

Ingram, D.L., C.R. Hall, and J. Knight. 2017a. Comparison of three production scenarios for Buxus microphylla var. japonica 'Green Beauty' marketed in a \#3 container on the west coast using life cycle assessment. HortScience 52:357-365.

Ingram, D.L., C.R. Hall, and J. Knight. $2017 \mathrm{~b}$. Modeling global warming potential, variable costs, and water use of young plant production system components using life cycle assessment. HortScience 52:1356-1361.

Ingram, D.L., C.R. Hall, and J. Knight. 2018 a. Global warming potential, variable costs, and water use of a model greenhouse production system for 11.4$\mathrm{cm}$ annual plant using life cycle assessment. HortScience 53:441-444.

Ingram, D.L., C.R. Hall, and J. Knight. 2018 b. Analysis of production system components of container-grown chrysanthemum for their impact on carbon footprint and variable costs using life 


\section{Reviews}

cycle assessment. HortScience 53:11391142 .

Ingram, D.L., C.R. Hall, and J. Knight. 2019. Production system components of container-grown Euphorbia pulcherrima: Impacts on carbon footprint and variable costs using life cycle assessment. HortScience (In press).

Intergovernmental Panel on Climate Change. 2006. Guidelines for national greenhouse gas inventories. Volume 4: Agriculture, forestry and other land use. Chapter 11: $\mathrm{N}_{2} \mathrm{O}$ emissions from managed soils, and $\mathrm{CO}_{2}$ emissions from lime and urea application. 13 Sept. 2018. <http://www.ipcc-nggip.iges.or.jp/ public/2006gl/vol4.html>.

International Organization for Standardization. 2006. Life cycle assessment, requirements and guidelines. ISO Rule 14044:2006. ISO, Geneva, Switzerland.
Kendall, A. and E.G. McPherson. 2012. A life cycle greenhouse gas inventory of a tree production system. Intl. J. Life Cycle Assess. 17:444-452.

Knight, J. and D.L. Ingram. 2017. Ecosystem services of landscape plants: A guide for green industry professionals. Univ. Kentucky Coop. Ext. Serv. Circ. HO- 115.

Knight, J. and D.L. Ingram. 2018. Ecosystem services of landscape plants: A guide for consumers and communities. Univ. Kentucky Coop. Ext. Circ. HO121.

United Nations. 2008. Kyoto protocol reference manual on accounting of emissions and assigned amounts. 1 Oct. 2018. <https://unfccc.int/resource/docs/ publications/08_unfccc_kp_ref_manual. pdf $>$.
United Nations. 2018. Intergovernmental panel on climate change. 13 Sept. 2018. <https://www.ipcc.ch>.

U.S. Environmental Protection Agency. 2018. Understanding global warming potentials. l Oct. 2018. <https://www. epa.gov/ghgemissions/understandingglobal-warming-potentials $>$.

Yue, C.Y., J.H. Dennis, B.K. Behe, C. R. Hall, B.L. Campbell, and R.G. Lopez. 2011. Investigating consumer preference for organic, local, or sustainable plants. HortScience 46:610 615.

Yue, C.Y., C.R. Hall, B.K. Behe, B.L. Campbell, J.H. Dennis, and R.G. Lopez. 2010. Are consumers willing to pay more for biodegradable containers than for plastic ones? Evidence from hypothetical conjoint analysis and nonhypothetical experimental auctions. J. Agr. Appl. Econ. 42:757-772. 